\title{
Editorial
}

\section{Editorial: Thank You to CORR's Peer Reviewers}

\author{
Seth S. Leopold MD
}

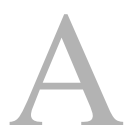

$s$ public debate continues over what is or isn't fake news, as some ask whether knowledge and experience are instead forms of elitism [1], and as we wonder if the 2016 Oxford word of the year ("post-truth" [4]) is planning to stick around just a bit longer, we at Clinical Orthopaedics and Related Research ${ }^{\circledR}$ would like to take this opportunity to acknowledge and thank a very special group of experts: CORR's peer reviewers. Our reviewers are essential

The author certifies that neither he, nor any members of his immediate family, have any commercial associations (such as consultancies, stock ownership, equity interest, patent/licensing arrangements, etc.) that might pose a conflict of interest in connection with the submitted article. All ICMJE Conflict of Interest Forms for authors and Clinical Orthopaedics and Related Research ${ }^{\circledR}$ editors and board members are on file with the publication and can be viewed on request.

The opinions expressed are those of the writers, and do not reflect the opinion or policy of $C O R R^{\circledR}$ or The Association of Bone and Joint Surgeons ${ }^{\circledR}$.

S. S. Leopold MD ( $\square)$

Clinical Orthopaedics and Related

Research $\AA, 1600$ Spruce St,

Philadelphia, PA 19103, USA

e-mail: sleopold@clinorthop.org to our mission-Disseminating Orthopaedic Knowledge-and they are fundamental to our operation. Without their continued generosity of time, care, and expertise, nothing else would be possible here.

This year at $C O R R^{\circledR}$, we saw new highs in almost every measurable parameter including usage (nearly 3 million full-text downloads, a threefold increase since 2011), Impact Factor (now at 3.897, up more than $50 \%$ over the last 5 years), and social-media visibility. I thank the authors who send their best work here, and I am proud of the tools our team has developed to help those authors present their work effectively (available for all to use at no charge at http://www.clinorthop.org/authorreviewer-tools). I believe our Senior Editors who work with CORR's authors on clarity and balance are the best medical editors in our profession. But good scientific reporting depends on good science, and for this, we need subject-matter experts. Our peer reviewers provide this expertise.

Because reviewing is so important, and because reviewers volunteer their time, we want to make it as easy as possible for our reviewers to do it both efficiently and to a high standard. Our reviewer tool [2] —also free for anyone to use, regardless of whether (s)he is performing a review for CORR, or for another journal-makes a difficult job faster and more consistent. It also can help readers to get more out of what they read, since it is focuses the reader's attention on the key questions that determine a study's validity [3]; it is available at http://www.clinorthop.org/ reviewertool, and is well worth a look if you have not seen it.

Since this time last year, more than 1800 individuals reviewed articles at CORR. My heartfelt thanks go to each one of them. In addition, I would like to recognize our top reviewers for 2017. These individuals performed four or more reviews in the last 12 months, and earned an average review-quality score in the "excellent" range. Fewer than $3 \%$ of our reviewers clear this high bar. We recognize their critical contributions by listing their names here (DOI: 10.1007/s11999017-5506-3), by providing each of them with a 1-year subscription to CORR, and (if they wish) by sending a letter of recognition for this considerable accomplishment to their institutions.

From the CORR family to yours, please accept our best holiday wishes for 2017, and a happy new year. 


\section{References}

1. Gage B. How 'elites' became one of the nastiest epithets in American politics. New York Times Magazine. January 3, 2017. Available at https:// www.nytimes.com/2017/01/03/magazine/ how-elites-became-one-of-the-nastiestepithets-in-american-politics.html? mcubz $=0$. Accessed on August 22, 2017.

2. Leopold SS: Editorial: CORR's new peer-reviewer tool-useful for more than peer reviews. Clin Orthop Relat Res. 2016;474:2321-2322.

3. Leopold SS: Editorial: Getting the most from what you read in orthopaedic journals. Clin Orthop Relat Res. 2017;475:1757-1761.

4. Oxford University Press. Word of the year 2016. Available at https://en.oxforddictionaries.com/word-of-theyear/word-of-the-year-2016. Accessed on August 22, 2017. 